\title{
USAGE OF GRAVITY MODEL IN EVALUATING FOREIGN TRADE BETWEEN BOSNIA AND HERZEGOVINA AND MONTENEGRO AS MEMBERS OF CEFTA AGREEMENT 2006
}

\author{
Ferhat Ćejvanović ${ }^{1}$, Dragovan Miličević ${ }^{2} \&$ Adnan Kamerić ${ }^{3}$
}

UDC / UDK: 339.5:519.862](497.6+497.16')

JEL classification / JEL klasifikacija; F12

DOI: https://doi.org/10.22598/pi-be/2018.12.1. 143

Review / Pregledni rad

Received / Primljeno: November 6, 2017 / 6. studenoga 2017.

Accepted for publishing / Prihvaćeno za tisak: June 11, 2018 / 11. lipnja 2018.

\section{Summary}

The analysis of foreign trade in global trading of today requires the usage of macro-analytical activities which are based on contemporary and classical evaluation methods, trading measurements and macroeconomic indicators of economic stability and growth. This paper starts from the idea and the need to evaluate the influence of foreign trade between Bosnia and Herzegovina using the gravity model. The aim of this paper has been set based on this idea and is reflected in the advantages and disadvantages of using the gravity model in evaluating foreign trade between Bosnia and Herzegovina and Montenegro.

The gravity method in foreign trade evaluates the potentials between some countries taking into consideration real trade value. It also takes into account the potential and costs of trading, as well as the distance of the analysed market. This paper starts accordingly from the assumption that the usage of the gravity model can evaluate the potential of import and export between two countries and in this way make assumptions about how to increase competitiveness among trading companies. The paper presents the potential for import and export from Bosnia and Herzegovina based on the results of the research. Sources of the data used in this paper are primarily the statistical publications of Bosnia and Herzegovina and Montenegro, as well as data available on the internet.

Key words: foreign trade, gravity model, evaluation, CEFTA agreement 2006, economic growth.

\footnotetext{
1 Ferhat Ćejvanović, External associate, University of Tuzla, Faculty of Economics,Tuzla, Bosnia and Herzegovina, E-mail: ferhat.cejvanovic@gmail.com

2 Dragovan Miličević, VIPOS, Valjevo Business School of Applied Studies, Serbia, E-mail: dragovan.milicevic@gmail.com

3 Adnan Kamerić, A Doctoral Student, University „Vitez“ Travnik, Bosnia and Herzegovina, E-mail: ado_ kamera@hotmail.com
} 


\section{INTRODUCTION}

Regional integrations take on different institutional forms, from the smallest to the most developed, depending on the number and type of obstacles for the movement of goods and all the factors of production that have remained. The model used in the analysis on this paper is the gravity model, which is usually evaluated on partner country/countries for a specific period using the cross-section (for one year) or the panel method (the interval of a few years).

The equation based on one country allows avoiding some usual problems related to cross-section or panel specification of the gravity model. This primarily refers to the distance of analysed countries as partners in trade, which affects the evaluation of the cross-section or the panel method depending on the geographical position of every country (Brenton and Di Mauro, 1998). The problem of unevenness of trading partner countries, which is related to the cross-section and panel specifications, is mitigated by the use of an equation with one country, which is why sometimes such specifications are used in literature (Brenton, Di Mauro and Lucke, 1999).

Frankel (1997) gives an overview of the literature trying to link the gravity analysis with different theoretical approaches such as the Heckscher-Ohlin theory and theory of imperfect substitutes. The answer to that question should be sought in appropriate theory of international exchange.

\section{TEORETICAL SETTINGS OF GRAVITY MODEL}

In its beginnings, the gravity analysis of trading flows was presented as an approach without proper theoretical foundations. However, as shown later on, the idea of using the economic potentials and trading costs in analysing trading flows was based more on theory than previously thought.

The gravity model for evaluating foreign trade was created on the example of Isaac Newton's law of physics, where the gravity force between bodies $A$ and $B$, with the masses $M a$ and $M b$ respectively, and with a distance $D a b$ between the two points is expressed by the formula:

$$
\mathrm{F}=\mathrm{cMaMb} / \mathrm{D} 2 \mathrm{a}, \mathrm{b} \quad \text { where } c \text { is the constant }
$$

In the gravity model of international trading, the equivalent is the force and range of trading between countries (e.g. total trading range, or components of import and export) between countries $i$ and $j$ (Tij), the mass is represented by the national income of the countries, GDP $i$ and GDP $j$ while the distance has kept its specification Dab:

$$
\mathrm{Ti}, \mathrm{j}=\mathrm{CGDPj} / \mathrm{Di}, \mathrm{j}
$$

The traditional approach to using the gravity model historically lies far more on the law of physics than on the postulates of economic theory, and in the past twenty to 
thirty years huge steps have been made in "synchronizing" economic theory with physical laws of nature.

A significant connection of economic theory with the Newton laws began with the work of Tinbergen (1962), and got a more coherent form with Anderson (1979). After Tinbergen and Anderson, there has been an increasing number of theoretical work setting the gravity models in the framework of economic theory. Here, we will briefly present the ideas of Anderson's classical work presenting the initial connection between economic theory and gravity laws of physics.

Anderson (1979) demonstrated the solution for consumption, under the assumption that Cob-Douglas functions can have the form of Isaac Newton's gravity equation.

Anderson's approach is basically simple and starts with the assumption of balanced trading between two countries. In his model, Anderson simplifies the reality by reducing the world to two countries, and also assumes that the proportion of domestic and foreign goods consumption is a constant and is independent from the level of income and tax policy. Therefore, the proportion of the income that consumer of country 1 spends on the consumption of goods imported from country 2 is a constant, and the same relation applies vice versa - the proportion of income that consumer of country 2 spends on the consumption of goods imported from country 1 is a constant.

If the following notation is adopted:

$\mathrm{Xi} \quad$ is the export from country $i$ to country $j$

$Y i \quad$ is country's income $i$

wj(i) proportion of the income that consumers of the country $i$ spend on consuming the products from the country $j$

Ii export from country $i$ to country $j$

$\mathrm{Ti}, \mathrm{j} \quad$ Trade land between countries $i$ and $j$

Therefore:

$$
\begin{aligned}
& X i=w i(j) Y j, \\
& I i=w j(i) Y j,
\end{aligned}
$$

Because of the assumption about balanced trading the following must be applied:

$$
\mathrm{Ti}, \mathrm{j}=\mathrm{Xi}+\mathrm{Ij}=2 w j(\mathrm{i}) \mathrm{Yj}=2 \mathrm{wj}(\mathrm{i}) \mathrm{Yj}
$$

In addition, the incomes of the country $i$ must, by definition, be equal to the sum of spent income on the consumption of domestic and foreign goods:

$$
Y i=w i Y i+w i Y j=w i(Y i+Y j)
$$

But if Yi+Yj is the world's consumption in a simplified model then we introduce the notation: 


$$
\text { Yof the worlds }=\mathrm{Ys}=\mathrm{Yi}+\mathrm{Yj}
$$

From (1) and (2) follows:

I.e.

$$
j=2 Y i Y j / Y j
$$

Equation (3) is a theoretical equation of (1) in a simplified world without friction.

According to this tradition, and taking into consideration the specificity of data, trading between countries can be an econometrical model as a combination of time series with cross-sectional elements:

$$
\text { TRj,k,t=CGDPj,tGDPk,t/Dj,k }
$$

where: (4)

$\mathrm{TRj}, \mathrm{k}, \mathrm{t}$ is trading from country $J$ to country $K$ in year $t$

C constant

GDPj,t Gross domestic product of country J in year $t$

GDPk,t Gross domestic product of country $K$ in year $t$

$D j, k \quad$ Distance between country J and country $K$

Data that enter the gravity model from the time series of several years is taken from statistic publications on the national as well as international level.

Parameters are set with the panel analysis, which is considered more appropriate than time series (data for exports for long periods are available in most countries) and cross-sectional data which are static in time. Panel data provides a higher number of observations than the time series and at the same time provide an insight in their changes in time. Due to a large number of countries and the observed period, every parameter of the model is rated with 168 observations. The model is evaluated with the low square method (OLS - ordinary least squares), parameters are determined by bringing in a relations independent variable with the required appearance of potential export, the multiple regression method.

Most of the data about export and import are taken from the statistics on foreign trade from statistic agencies, and it is also possible to download the data from international publications.

In estimates, the gravity model mostly includes variables such as GDP or GDP per capita of the importing and exporting country, the population number for both countries, distance between the generating and receptive market, the common border, preferential arrangements etc.

The most important task in the gravity model is to determine the parameters (coefficient) which correspond to the given factors: 


$$
\beta 1, \beta 2, \beta 3, \beta 4, \beta 5, \beta 6
$$

because they determine the extent to which the individual independent variable (country's GDP, distance, economic-political distance) affects the dependent variable (import-export). Coefficients show which of the given variables are significant for import and export of one country and to what extent this is going to be included in the model (equation).

In the gravity model the following variables have been tested:

Gross domestic product is marked for the most important import and export destinations considering the value of import and export. A large number of countries that figure as the biggest receptive markets for the country's products are included according to the ranking of the country's statistics in available publications. The data is provided by the national agency for statistics, as well as the World Bank and sites www. trademap.org and www.intracen.org.

In the use of gravity model, the expected sign is positive, because the purchasing power sets the range of import to a great extent. Equally often GDP per capita is used, but in this model the demand is largely determined by the total GDP. Namely, total GDP explains the size of the receptive market, which has a higher significance for export than the purchasing power of individuals. Although the most common variable in the gravity model, GDP of the receptive market shows a relatively weak relation (small coefficient of correlation) with the country's export. Notwithstanding, this variable is included in the model because it still shows a statistical significance and because together with other factors it contributes to the explanation of the observed phenomena.

GDP showed in the model has a greater influence on export than on the GDP of receptive markets. The connection between economic growth and export growth has proved to be more direct and influential. In simple regression, this variable would have a coefficient of determination around 0,31 ; it would explain almost a third of the change in export value.

Transport costs in the export of any product have a significant influence on demand. Transport costs are mostly used for the distance of trade markets. The effects of trade reduction are the strongest in transport-intensive activities - activities which are dependent on the import and export of semi-goods. Even when transport and communicational costs are reduced in time, the distance continues to significantly affect the local income. The improvement of transport and communication (the development of channels, roads, internet, airport network, post office, telegraph, telephone) does not reduce the importance of distance. New technologies, as well as liberalization of the trading policy, can certainly resize some of the transport costs, but many of their aspects still exist. Because of this, the most significant trading partners are always the neighbouring countries. However, export directions are by no means depleted in European countries. The model obtained in the manner described shows that export significantly depends on geographical distance, which is negatively related to the range of export. The influence of the distance on export is so strong that in simple regression, taken as the only factor of export, it would participate with $57 \%$ of the export value. 
Population is a common variable in the export gravity model, because it connects the size of the market with export value.

Economic-political distance between two countries cannot be measured, so we use a dummy, an artificial variable, evaluating it by zero or one economic relation and the institutional basis for its improvement. The data used for the evaluation of this variable are taken mostly from the country's Ministry of foreign affairs, which gives a detailed overview of bilateral contracts and agreements regulating economic cooperation, and an overview of the range and purpose of mutual investments, mutual projects of expert training, the presence of specific companies etc. The artificial variable $\mathrm{P}$ takes the value 1 if there are certain preferential arrangements, agreements on trading convenience, a significant volume of investment in the economy, presence of companies and other, while it takes the value 0 if economic cooperation is relatively underdeveloped and unregulated. This factor in the model of export has showed a big influence - in simple regression, as the only factor it would explain $28 \%$ of the changes in export value.

This procedure calculates the value of a constant obtained by multiple regression, as well as the parameters which correspond to the factors included in regressive analysis. In addition to these values, which will be applied later in the model, every error of a constant and each parameter is given, as well as P-value which indicates the statistical probability for each one of them. Since countries included in testing the model have a large number of observations, the obtained model and coefficients are not limited to any region, but they can be used for calculating the export potential of any country or region of the world.

However, the model evaluating the gravity model coefficient of foreign trade has several significant deficiencies:

High standard errors of the coefficient which point to the fact that they cannot adequately represent the state of occurrence and its influence;

The explained variability is $70 \%$ of occurrence which means that $30 \%$ of researched occurrence belongs to unexplained variability and this kind of evaluation cannot be econometrically valid;

$\mathrm{P}$ - the value of the coefficient is significantly high, pointing to the fact that coefficients significantly differ from the acceptable intervals of confidence of 95-99\%;

The evaluation of model parameters by applying additional statistic-econometric equipment would go beyond the possibilities of this project and would not provide the wanted result.

As an alternative to this model in practice the model of bilateral exchange based on evaluated model parameters by L.A. Winters and Z. K. Wang is often used, and is applied in this case.

The basic form of the gravity model of international trade is:

$$
\begin{gathered}
\ln X_{i j}=\alpha+\beta_{1} \ln Y_{i}+\beta_{2} \ln N_{i}+\beta_{3} \ln Y_{i}+\beta_{4} \ln N_{i}+ \\
+\beta_{5} \ln D_{i j}+\beta_{6} \ln A_{i j}+\sum_{k} \gamma_{k} \ln P_{i j k}+u_{i j}
\end{gathered}
$$


Where:

$\alpha \quad$ - constant

$X_{i j} \quad$ - trade value which is instructed from country i to country $j$,

$Y_{i}, Y_{j}-G D P$ of the countries $i$ and $j$,

$N_{i}, N_{j}$ - total population of countries $i$ and $j$,

$D_{i j} \quad$ - distance between countries $i$ and $j$,

$A_{i j} \quad$ - dummy variable representing the common border,

$P_{i j k} \quad$ - dummy variable for the existence of preferential arrangements or belonging to the same economic grouping,

$u_{i j} \quad$ - random model error.

This model can be applied on a country's trading with every country that appears to be interesting for determining the potential of export. The data about the country's trading and GDP is usually expressed in US dollars, euros or another strong global currency. Experience shows that "trademap" and "intracen" data are very useful. Population is expressed in millions and the distance in kilometres.

The model has been rated by using the OLS method (ordinary least squares OLS). Results show that the coefficient ratings are statistically important and logical. The gravity model is used for bilateral trading of one country with neighbouring countries. The aim is to determine the potential range of export in each country in the region, and then to compare with existing export. Simply said, the aim is to determine whether and by how much the export of one country to analysed countries can be increased. Chart 1 shows the coefficients for the use of the gravity model.

Chart 1: Coefficient for the application of the gravity model

\begin{tabular}{|c|c|c|c|c|}
\hline $\ln X i j$ & Koefrijent & St. greška & $t$ & $P=1 t$ \\
\hline $\ln Y i$ & 0.930705 & $0.031002 ?$ & 3002 & 0.000 \\
\hline $\ln \mathrm{W}_{\mathrm{i}}$ & 0.0246554 & 0.0386548 & 0.64 & 0.524 \\
\hline $\ln Y j$ & 0.6829835 & 0.0310023 & 2203 & 0.000 \\
\hline $\ln \mathrm{lJj}_{\mathrm{j}}$ & 0.0473422 & 0.0386642 & 1.22 & 0.221 \\
\hline $\ln \mathrm{Dij}$ & -1.222391 & 0.0598855 & -20.41 & 0.000 \\
\hline$A \ddot{y}$ & 0.6401405 & 0.1234944 & 5.18 & 0.000 \\
\hline $\mathrm{Pij}$ & 0.5789241 & 0.1033485 & 5.60 & 0.000 \\
\hline cons & -4.655665 & 0.5933037 & -7.85 & 0.000 \\
\hline
\end{tabular}

Source: Winters L.A., Wang, Z.K. Eastern Europe's international trade Manchester University Press, Manchester and New York, 1994. 
According to the gravity model formula, potential export from country $i$ to country $j$ is established by the following:

- all known values - multi-annual average of GDP of exporting country,

- multi-annual average of GDP of importing country,

- population of importing and exporting country and

- distance between them is multiplied with appropriate parameters of Winters and Wang.

Artificial variables take the value 2 if the countries share the same border or belong to the same economic group, or 1 if this is not the case. They are also multiplied by appropriate parameters and then added to the sum. For cross-section models, the characteristic problem is that of heteroscedasticity, because of the nature of the data itself and certain deficiencies of this model. On the one hand, there are large variations of data during just one year, and on the other hand, which is more important and characteristic for economic occurrences, it is impossible to explain the variations of the dependent variable, as much as we include them into the model. The unexplained factors are included in the model through the independent variables and accumulate in residues. With the variations of independent variables and variations of random error ( $i$ and $j$ ), they vary and are not equal, which is the assumption of the heteroscedasticity. The problem of removing the heteroscedasticity in cross-section models go beyond the possibilities of this paper. It is certain that specific inconsistencies of the gravity model exist, but they are accepted (and mostly removed), because the analytical value of the multiple results is obtained and this is why the gravity model is still used in empirical research.

The gravity model is a relatively intuitive description of trading flows between countries whose grounds are based on the principles of physical laws of gravity. Simply put, and taken directly from Newton's laws, the theory of the gravity model of international trade formulates the proposition which suggests that trading flows between two countries grow because the GDP of those countries is higher, and decrease with the increase of distance between two countries, which in the specification of a model serves as a simplified representation of transport costs.

The gravity models are often the subject of academic criticism which points out that the usage of a natural physical principle excessively simplifies the reality of real trading flows. In addition, technological innovations increasingly allow for more direct and indirect observation of the trading flows, sometimes eliminating the need for a theoretical approach in modelling trade relations in the way of the gravity models.

For example, apart from presenting international trading flows, the gravity models often use historical and present macroeconomic, trading and demographic trends to model and represent the future consumer habits. This analysis usually requires precise geographical data, so that the demographic and economic statistics can go to the tiniest geographic micro level, i.e. the level of a region, city or even a part of a city. The purpose of this type of gravity model is to use the statistics, such as the structure and increase 
of a population, employment, retail sales, available revenues, density and quality of the traffic network, proximity to large public transport hubs etc. to predict future consumer demand, as well as optimal places for locating new malls, supermarkets, stores etc.

However, technological innovations, especially the development of computer technologies, offer better possibilities for gathering, analysing and processing data, and this is the way large trading chains get the possibility of a direct observation of consumer habits. The most obvious example are the chains of supermarkets and their successful loyalty schemes, which offer benefits both to the consumer and the trading chain. Consumers using the loyalty card get a consumer discount which can be unique in that it designed and aimed at the consumer habits of a concrete consumer, where discount is designed and directed towards the group of products that a specific consumer usually consumes. At the same time, the loyalty card offers supermarkets the information about consumers which include the name and the address of a consumer, products that the consumer usually buys as well the places where he buys them. The supermarket can observe the individual consumer in real time, what the consumer buys, how long he travels to the supermarket, and it can use this information for its future business strategy and opening new stores, as well as for optimizing the logistic network. Therefore, the gravity model becomes increasingly an obsolete methodology for supermarkets, because it offers just the approximation of consumer habits, which the supermarkets can be increasingly more precise and better at observing in real time.

Criticism of the gravity model of international trading is of a different nature, because there is no way to observe international trade in real time. The underlying criticism of the gravity model of international trade is that it is ignoring a whole set of socio-economic and social factors which determine the level of trading between two countries. Therefore, apart from the combined size of economies, their distances, the critics of the gravity model point out that factors such as possible differences in economic policies of two countries, differences in their membership of custom unions and associations, participation in international trading agreements, as well as comparative advantages and disadvantages of two economies, also have a significant impact, and they are not taken into account by the gravity model. Also, trade between countries is increasingly becoming a trade in services, which often does not leave a "physical trail" in the same way a store does in a classical sense, and for which the geographical proximity of a market does not represent a comparative advantage or savings.

Despite its critics, the gravity model is considered to be empirically among the most successful, and explains relatively well the relations and changes in the world trade. Although critics can point out that a positive relation with GDP and negative one with distance can be a "cover" for many different economic assumptions, the results of the model are very often in line with reality, which makes the usage of the model more popular and attractive. 


\section{RESULTS OF FOREIGN TRADE EVALUATION BETWEEN BOSNIA AND HERZEGOVINA AND MONTENEGRO AS MEMBERS OF CEFTA AGREEMENT 2006 USING THE GRAVITY MODEL}

Export growth is the basis for economic growth of each country and disputes over that get a special place, not just on an academic level, but in wider professional and public circles. The problem is identifying the possibility of export-oriented growth, i.e. which macroeconomic policies are directed towards regional reorientation. In this connection, the analysis of foreign trade was carried out using the gravity model between Bosnia and Herzegovina and Montenegro.

Chart 2 shows the value of exports from Montenegro to the world and to Bosnia and Herzegovina. The presented data are the basis for applying the gravity model in foreign trade between Montenegro and Bosnia and Herzegovina.

Chart 2: Export value from Montenegro to the world and Bosnia and Herzegovina (000 American dollars)

\begin{tabular}{|c|c|c|r|r|r|r|r|r|}
\hline Export & $\begin{array}{c}\text { Export } \\
\text { value in } \\
\mathbf{2 0 0 6}\end{array}$ & $\begin{array}{c}\text { Export } \\
\text { value in } \\
\mathbf{2 0 0 7}\end{array}$ & $\begin{array}{c}\text { Export } \\
\text { value in } \\
\mathbf{2 0 0 8}\end{array}$ & $\begin{array}{c}\text { Export } \\
\text { value in } \\
\mathbf{2 0 0 9}\end{array}$ & $\begin{array}{c}\text { Export } \\
\text { value in } \\
\mathbf{2 0 1 0}\end{array}$ & $\begin{array}{c}\text { Export } \\
\text { value in } \\
\mathbf{2 0 1 1}\end{array}$ & $\begin{array}{c}\text { Export } \\
\text { value in } \\
\mathbf{2 0 1 2}\end{array}$ & $\begin{array}{c}\text { Export } \\
\text { value in } \\
\mathbf{2 0 1 3}\end{array}$ \\
\hline World & 556,459 & 629,289 & 616,616 & 387,540 & 436,575 & 627,532 & 468,788 & 494,376 \\
\hline $\begin{array}{c}\text { Bosnia and } \\
\text { Herzegovina }\end{array}$ & 23,224 & 22,688 & 29,398 & 24,925 & 31,865 & 31145 & 35,217 & 24,395 \\
\hline
\end{tabular}

Source:(2016) trademap.org

When discussing the main characteristics of Montenegro's export it can be concluded that it has the smallest share of export outside Europe among European countries. Among the European countries, it has the lowest unit value of exports. Montenegro's export has a high share of total exports directed towards a small number of countries, and most of them are the countries in its close surroundings.

By using these basic characteristics of Montenegro's export to Bosnia and Herzegovina, the usage of the gravity model can "highlight" the directions and export growth. However, the gravity model cannot provide the answers about why the state is as it is, i.e. why its exports are sliced into a multitude of products, why they are highly concentrated on a small number of countries, with a low unit value of placed goods.

\subsection{Evaluation of the gravity model for import from Montenegro to Bosnia and Herzegovina}

In this part of the work the import from Montenegro to Bosnia and Herzegovina will be shown. For the purposes of unifying the monitoring of statistical data and 
making it uniform, trading between Montenegro and Bosnia and Herzegovina will be shown in the value of US dollars.

During the evaluation of the distance variable, the used data stand for the distance between capital cities of the mentioned countries, i.e. from Podgorica to Sarajevo in road traffic according to the data from the site www.udaljenost.com.

\subsubsection{Evaluation of import from Montenegro to Bosnia and Herzegovina applying the gravity model}

Indicators and results of the gravity model for import from Montenegro to Bosnia and Herzegovina are shown in Chart 3.

Chart 3: Results of the gravity model for import from Montenegro to Bosnia and Herzegovina

\begin{tabular}{|l|r|r|r|r|r|r|r|}
\hline & $\begin{array}{c}\text { Yi } \\
\text { GDP of } \\
\text { Monte- } \\
\text { negro }\end{array}$ & $\begin{array}{c}\text { Ni } \\
\text { Population } \\
\text { of } \\
\text { Monte- } \\
\text { negro }\end{array}$ & $\begin{array}{c}\text { Yj } \\
\text { GDP of } \\
\text { Bosnia and } \\
\text { Herzegovina }\end{array}$ & $\begin{array}{c}\text { Nopulation } \\
\text { of } \\
\text { Bosnia and } \\
\text { Herzegovina }\end{array}$ & $\begin{array}{c}\text { Nij } \\
\text { Distance in } \\
\text { kilometres }\end{array}$ & $\begin{array}{c}\text { Aij } \\
\text { Dummy } \\
\text { Variable } \\
\text { Border }\end{array}$ & $\begin{array}{c}\text { Pijk } \\
\text { Dummy } \\
\text { variable } \\
\text { trade } \\
\text { grouping }\end{array}$ \\
\hline Ln & 7,429 & 0,65 & 32,160 & 4,62 & 229 & 2 & 2 \\
-4.655 & 8.9131 & -0.4308 & 10.3785 & 1.5304 & 5.4337 & 0.6931 & 0.6931 \\
rated & 0.9370 & 0.0240 & 0.6800 & 0.0470 & -1.2220 & 0.6401 & 0.5789 \\
parameters & 8.3516 & $-0,0103$ & 7.0574 & 0.0719 & -6.6400 & 0.4437 & 0.4013 \\
& & & & & & & \\
& & & & & & & \\
& & & & & & & \\
\end{tabular}

Source: calculation of the author based on the data http://www.trademap.org/ (consulted 20.11.2016)

In Bosnia and Herzegovina, the potential of import from Montenegro is about 149 million dollars. Import to Bosnia and Herzegovina was about 30 million dollars in average for the analysed period. Considering all preconditions, Montenegro's economy has the possibility of significantly increasing trading with Bosnia and Herzegovina. Potential based on the gravity model is five times higher than the real import to Bosnia and Herzegovina from Montenegro.

\subsubsection{Import from Montenegro to Bosnia and Herzegovina according to the most common trade marks}

Import from Montenegro to Bosnia and Herzegovina according to most common trade marks is explained in Chart 4. 
Chart 4: Import from Montenegro to Bosnia and Herzegovina according to most common trade marks

\begin{tabular}{|l|l|c|c|c|}
\hline \multirow{2}{*}{$\begin{array}{c}\text { Tariff } \\
\text { chapter }\end{array}$} & \multicolumn{1}{|c|}{ Trade marks } & \multicolumn{3}{c|}{$\begin{array}{c}\text { Export from Montenegro to } \\
\text { Bosnia and Herzegovina }\end{array}$} \\
\cline { 3 - 5 } & & Value in 2011 & Value in 2012 & Value in 2013 \\
\hline TOTAL & All products & 31,145 & 35,217 & 24,395 \\
\hline '41 & Raw hide (except fur) & 4,641 & 4,442 & 4,732 \\
\hline '22 & Drinks, alcohol and vinegar & 8,546 & 5,152 & 3,749 \\
\hline '16 & Meat, fish and seafood, other food products & 2,913 & 2,470 & 2,343 \\
\hline '02 & Meat and meat products & 1,541 & 1,663 & 1,919 \\
\hline '27 & Mineral fuels, oils, means for distillation & 1,604 & 1,109 & 1,767 \\
\hline '84 & Machines, nuclear reactors, boilers, etc. & 1,814 & 944 & 1,288 \\
\hline '07 & Vegetables and certain roots and grain & 507 & 263 & 1,169 \\
\hline '26 & Ore, slag and ash & 291 & 234 & 1,098 \\
\hline '30 & Pharmaceuticals products & 1,204 & 1,627 & 1,001 \\
\hline '87 & Vehicles, except railway, trams & 357 & 144 & 809 \\
\hline
\end{tabular}

Source http://www.trademap.org/ (consulted 25.11.2016)

Import to Bosnia and Herzegovina from Montenegro is mainly concentrated on rawhide, drinks, fish and seafood.

Bosnia and Herzegovina imports mainly the products of low added value (raw and labour intensive activities) from Montenegro, which suggests that the extent of the imported offer is conditioned by a low level of development of the economy itself.

Chart 5 shows complementarity of Montenegro's export supply and Bosnia and Herzegovina's demand. 


\begin{tabular}{|c|c|c|c|c|c|c|c|c|c|c|c|c|}
\hline & 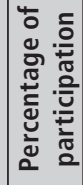 & . & 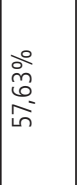 & $\frac{\stackrel{\circ}{m}}{\frac{m}{n ! n}}$ & $\begin{array}{l}\stackrel{0}{2} \\
\stackrel{0}{0} \\
\text { ơ }\end{array}$ & 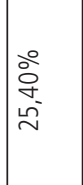 & $\stackrel{\stackrel{\circ}{\rightleftharpoons}}{\stackrel{\sim}{~}}$ & 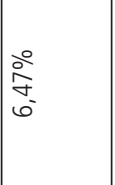 & $\begin{array}{l}0 \\
\infty \\
0 \\
\infty \\
\infty \\
-\end{array}$ & $\mid \begin{array}{l}\stackrel{0}{2} \\
\infty^{-}\end{array}$ & $\begin{array}{l}\text { 亏 } \\
\text { Оे }\end{array}$ & 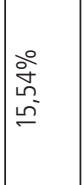 \\
\hline \multirow{3}{*}{ 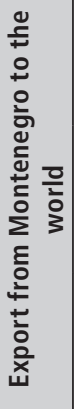 } & 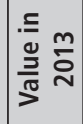 & \begin{tabular}{|c|}
$\stackrel{0}{ }$ \\
$\stackrel{2}{n}$ \\
$\stackrel{+}{\sigma}$ \\
\end{tabular} & $\underset{\substack{\bar{N} \\
\infty}}{\bar{\infty}}$ & 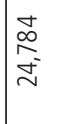 & $\mid \begin{array}{l}\overline{\bar{\infty}} \\
\sigma^{-}\end{array}$ & $\begin{array}{l}\text { 总 } \\
\stackrel{n}{N} \text {. }\end{array}$ & $\mid \begin{array}{l}\overline{\bar{g}} \\
\text { 弟 }\end{array}$ & 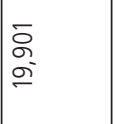 & $\begin{array}{l}\qquad \begin{array}{l}n \\
0 \\
0 \\
0\end{array}\end{array}$ & $\mid \begin{array}{l}\bar{a} \\
\overline{0} \\
\stackrel{1}{y}\end{array}$ & $\begin{array}{l}\stackrel{\circ}{\circ} \\
\infty_{\infty} \\
\infty\end{array}$ & $\begin{array}{l}\text { ì } \\
\text { in }\end{array}$ \\
\hline & 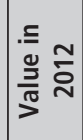 & $\left|\begin{array}{c}\infty \\
\infty \\
o \\
o 0 \\
o b \\
0\end{array}\right|$ & $\begin{array}{l}\frac{6}{m} \\
\text { n. }\end{array}$ & $\begin{array}{l}\bar{\infty} \\
\infty \\
\text { Dे }\end{array}$ & $\begin{array}{l}\tilde{N} \\
\text { m. }\end{array}$ & 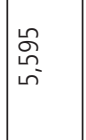 & $\mid \begin{array}{l}\overline{\tilde{m}} \\
\infty \\
\bar{f}\end{array}$ & $\begin{array}{l}\frac{n}{2} \\
m \\
\stackrel{n}{i}\end{array}$ & $\underset{\sim}{\stackrel{\tilde{\sigma}}{\sim}}$ & $\begin{array}{l}\infty \\
\stackrel{\infty}{q} \\
\sigma \\
\sigma\end{array}$ & 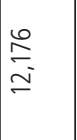 & $\underset{\underset{\sim}{\stackrel{\infty}{\sim}}}{\stackrel{\infty}{\sim}}$ \\
\hline & .气 & 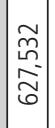 & $\begin{array}{l}n \\
0 \\
0 \\
0 \\
6\end{array}$ & $\frac{\sqrt{\tilde{n}}}{\frac{\tilde{n}}{m}}$ & $\begin{array}{l}\frac{m}{\omega} \\
m\end{array}$ & $\begin{array}{l}\stackrel{\circ}{o} \\
\stackrel{m}{\sigma} \\
\text {. }\end{array}$ & 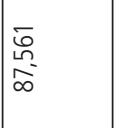 & 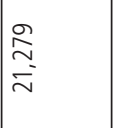 & 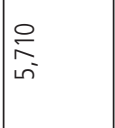 & $\begin{array}{l}\text { } \\
\infty \\
\stackrel{\sim}{\simeq}\end{array}$ & $\mid \begin{array}{l}\overline{1} \\
0 \\
0 \\
0\end{array}$ & $\begin{array}{l}\text { ટ્ } \\
\text { हn }\end{array}$ \\
\hline \multirow{3}{*}{ 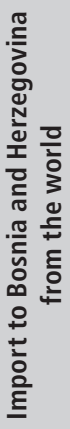 } & 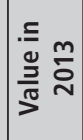 & 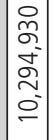 & $\begin{array}{l}\text { 吕 } \\
6 \\
\infty \\
o^{-} \\
\text {N }\end{array}$ & 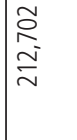 & 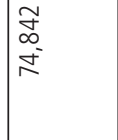 & 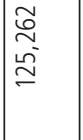 & 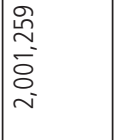 & 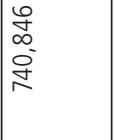 & 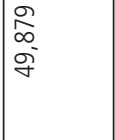 & $\begin{array}{l}m \\
\infty \\
\infty \\
\sim \\
\sim\end{array}$ & 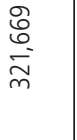 & $\begin{array}{l}\stackrel{0}{6} \\
6 \\
\mathbb{\tau} \\
6\end{array}$ \\
\hline & 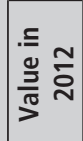 & $\left|\begin{array}{l}\hat{0} \\
0 \\
0 \\
0 \\
0 \\
0 \\
0\end{array}\right|$ & $\begin{array}{l}\infty \\
0 \\
\vdots \\
\vdots \\
i\end{array}$ & 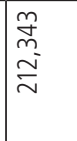 & 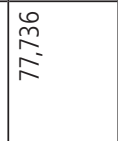 & $\mid \begin{array}{l}\hat{\hat{b}} \\
\infty \\
\infty \\
\infty\end{array}$ & 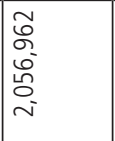 & $\begin{array}{l}\underset{i n}{\tilde{n}} \\
\underset{n}{n}\end{array}$ & 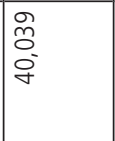 & $\underset{\mathrm{O}}{\stackrel{\sim}{\sigma}}$ & 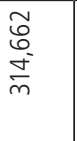 & 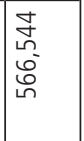 \\
\hline & .气 & \begin{tabular}{|l|}
\multirow{2}{n}{} \\
$\tilde{\omega}$ \\
0 \\
0 \\
0 \\
$=$ \\
$=$ \\
\end{tabular} & $\begin{array}{l}\text { స̃ } \\
\text { مू } \\
\text { Dे } \\
\text { }\end{array}$ & 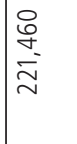 & 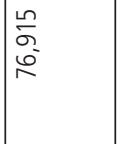 & $\begin{array}{l}\infty \\
\infty \\
\infty \\
\sigma \\
\sigma \\
\end{array}$ & 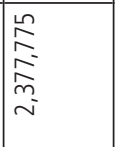 & 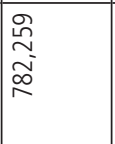 & \begin{tabular}{|l|}
\multirow{2}{*}{} \\
$\infty$ \\
\multirow{y}{*}{} \\
\end{tabular} & 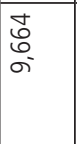 & 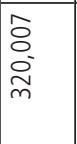 & 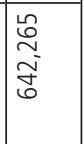 \\
\hline \multirow{3}{*}{ 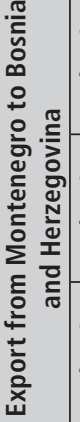 } & 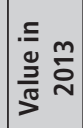 & 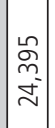 & 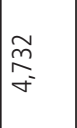 & $\frac{g}{\stackrel{g}{m}}$ & $\underset{\substack{\stackrel{m}{\sim} \\
\sim}}{ }$ & $\stackrel{\stackrel{\sigma}{\sigma}}{\stackrel{2}{-}}$ & $\mid \begin{array}{l}\frac{1}{2} \\
=\end{array}$ & 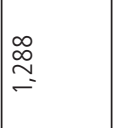 & $\stackrel{\mathscr{O}}{\stackrel{\mathscr{O}}{二}}$ & 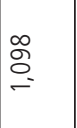 & 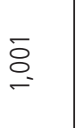 & ஓे \\
\hline & 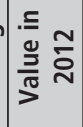 & 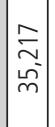 & 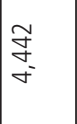 & $\begin{array}{l}\text { ñ } \\
\text { En }\end{array}$ & 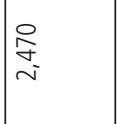 & 蒿 & $\stackrel{\stackrel{9}{\circ}}{=}$ & 志 & $\ddot{\mathscr{N}}$ & $\stackrel{\sim}{\sim}$ & $\underset{\widetilde{\sigma}}{=}$ & $\stackrel{\Xi}{\Xi}$ \\
\hline & 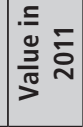 & $\frac{\stackrel{\leftrightarrow}{f}}{\stackrel{m}{m}}$ & $\begin{array}{l}\overline{\mathcal{G}} \\
\sigma \\
\sigma\end{array}$ & \begin{tabular}{l}
0 \\
\multirow{1}{0}{} \\
$\infty^{\circ}$
\end{tabular} & 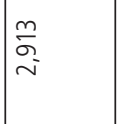 & $\stackrel{\bar{f}}{\stackrel{\Sigma}{\alpha}}$ & $\underset{\stackrel{d}{0}}{\stackrel{\leftrightarrow}{-}}$ & 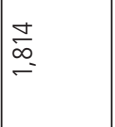 & 옹 & হু & 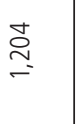 & $\stackrel{\hat{m}}{m}$ \\
\hline & 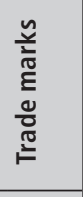 & $\begin{array}{l}0 \\
\frac{\tilde{z}}{0} \\
\frac{0}{2} \\
\overline{\bar{\alpha}} \\
\end{array}$ & 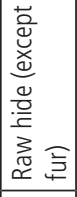 & 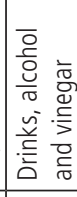 & 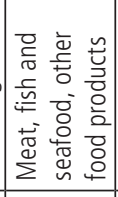 & 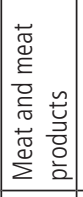 & 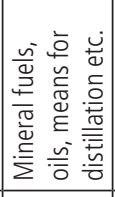 & 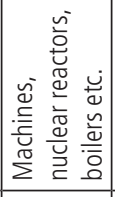 & 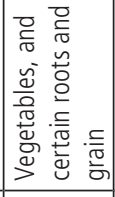 & 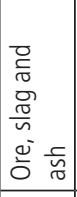 & 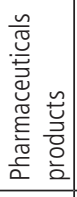 & 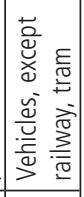 \\
\hline & 荘 & 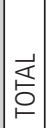 & 于 & $\approx$ & 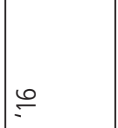 & $\widetilde{\sigma}$ & $\lesssim$ & $\Phi$ & 우 & $\stackrel{\gtrless}{\sim}$ & $\stackrel{\oplus}{ }$ & $\infty$ \\
\hline
\end{tabular}


Potentials are significantly above real indicators. However, it is important to point out that Montenegro has suboptimal export supply due to real potentials of neighbouring countries' demand in terms of the exporting offer with Bosnia and Herzegovina.

\subsection{Real terms of export from Bosnia and Herzegovina to Montenegro}

Chart 6. shows the real terms of export from Bosnia and Herzegovina to Montenegro

Chart 6: Real terms of export from Bosnia and Herzegovina to Montenegro (in 000 American dollars)

\begin{tabular}{|c|c|c|c|c|}
\hline \multirow{2}{*}{$\begin{array}{l}\text { Tariff } \\
\text { chapter }\end{array}$} & \multirow{2}{*}{ Products } & \multicolumn{3}{|c|}{$\begin{array}{c}\text { Export from Bosnia and Herzegovina } \\
\text { to Montenegro }\end{array}$} \\
\hline & & $\begin{array}{c}\text { Value in } \\
2011\end{array}$ & $\begin{array}{l}\text { Value in } \\
2012\end{array}$ & $\begin{array}{l}\text { Value in } \\
2013\end{array}$ \\
\hline TOTAL & All products & 193,672 & 158,146 & 167,543 \\
\hline$' 28$ & $\begin{array}{l}\text { Inorganic chemicals, precious metal compounds, } \\
\text { isotopes }\end{array}$ & 71,977 & 46,594 & 34,529 \\
\hline '72 & Iron and steel & 20,822 & 17,071 & 19,674 \\
\hline '04 & Dairy products, eggs honey & 4,974 & 5,683 & 17,605 \\
\hline '73 & Products from iron and steel & 13,676 & 14,624 & 12,552 \\
\hline '27 & Mineral fuels, oil, distillation products, etc. & 29,205 & 14,673 & 12,254 \\
\hline 39 & Plastics and plastic products & 3,890 & 3,564 & 5,565 \\
\hline 44 & Wood and wooden products, wooden coal & 3,491 & 3,108 & 4,267 \\
\hline 48 & $\begin{array}{l}\text { Paper and cardboard, cellulose and paper } \\
\text { products }\end{array}$ & 3,911 & 4,376 & 4,182 \\
\hline '76 & Aluminum and aluminum products & 3,462 & 3,997 & 4,171 \\
\hline '85 & Electrical, electronical equipment & 2,451 & 3,391 & 4,106 \\
\hline
\end{tabular}

Source http://www.trademap.org/ (consulted 20.10.2016)

Main export products from Bosnia and Herzegovina to Montenegro are various inorganic chemicals, iron and steel, as well as dairy products like eggs and honey. Also, electricity, fossil fuels, coke etc. are exported from Bosnia and Herzegovina. 


\subsection{Evaluation of the export from Bosnia and Herzegovina to Montenegro by applying the gravity model}

Gravity model results of export from Bosnia and Herzegovina to Montenegro are shown in Chart 7.

Chart 7: Gravity model results of export from Bosnia and Herzegovina to Montenegro

\begin{tabular}{|l|r|r|r|r|r|r|r|}
\hline & $\begin{array}{c}\text { Yi } \\
\text { GDP of } \\
\text { Bosnia and } \\
\text { Herzegovina }\end{array}$ & $\begin{array}{c}\text { Ni } \\
\text { Population of } \\
\text { Bosnia and } \\
\text { Herzegovina }\end{array}$ & $\begin{array}{c}\text { Yj } \\
\text { GDP of } \\
\text { Montenegro }\end{array}$ & $\begin{array}{c}\text { N1 } \\
\text { Population } \\
\text { of } \\
\text { Montenegro }\end{array}$ & $\begin{array}{c}\text { Dij } \\
\text { Distance } \\
\text { in } \\
\text { kilometres }\end{array}$ & $\begin{array}{c}\text { Aij } \\
\text { Dummy } \\
\text { Variable } \\
\text { Border }\end{array}$ & $\begin{array}{c}\text { Pijk } \\
\text { Dummy } \\
\text { variable } \\
\text { trade } \\
\text { grouping }\end{array}$ \\
\hline Ln & 32.160 & 4.62 & 7.429 & 0.65 & 229 & 2 & 2 \\
-4.655 & 10.3785 & 1.5304 & 8.9131 & -0.4308 & 5.4337 & 0.6931 & 0.6931 \\
rated & 0.9370 & 0.0240 & 0.6800 & 0.0470 & -1.2220 & 0.6401 & 0.5789 \\
parameters & 9.7246 & 0.0367 & 6.0609 & -0.0202 & -6.6400 & 0.4437 & 0.4013 \\
& & & & & & & \\
& & & & & & & \\
& & & & & & & \\
\end{tabular}

Source: author's calculation based on the data http://www.trademap.org/ (consulted 20.12.2016)

The potential export from Bosnia and Herzegovina is 207 million dollars and is higher than the real export indicators that amount to 149 million dollars.

\section{CONCLUSION}

In modern conditions which are characterised by the growing importance of trade, relations of one country with the international environment play an important role for the country's economic development. In the last few decades, the process of economic integration, through the removal of the barriers to the free movement of goods, services, money and people, has been enhanced by opening new work places and increasing economic activity.

The results of a gravity model are very often in line with reality, which makes the use of the model popular and attractive. Variables like the Gross Domestic Product or Gross Domestic Product per capita, agricultural gross domestic product of importing and exporting countries, both countries' population numbers, distance between the generating and receptive market, common border, preferential arrangements etc. are mostly included in the gravity model.

In the assessment the gravity model, variables like GDP or GDP per capita of analysed countries have been used, as well as the population number of both countries, distance between those countries, common points in preferential trade arrangements or special bilateral and multilateral agreements and relations. 
The usage of gravity model in this research has resulted in the conclusion that potential import to Bosnia and Herzegovina from Montenegro is 149 million dollars, while the real import is about 30 million dollars. Potential export from Bosnia and Herzegovina to Montenegro is 207 million dollars. The gravity model has created a "space“ for additional 58 million dollars for Bosnia and Herzegovina.

It is important to point out that gravity models do not contain essential data about the import/export structure nor of the influence of the movement of capital between countries, intra-industrial trade, the possibility for a neighbouring country or trade area countries to have dependent companies in other countries where trade between "mother" and "daughter" represents trading of two companies which does not reflect the real state.

\section{REFERENCES:}

1. Anderson, J. (1979) A Theoretical Foundation for the Gravity Equation, American Economic Review, 1979, vol. 69, issue 1, 106-16

2. Brenton, P. and Di Mauro, F. ( 1998) Is There Any Potential in Trade in Sensitive Industrial Products Between the CEECs and the EU?. The World Economy, (21), 285- 304.

3. Brenton, P., Di Mauro, F. and Lucke, M. (1999) Economic integration and FDI: an empirical analysis of foreign investment in the EU and in Central and Eastern Europe, Empirica, (26), 95-121.

4. Ćejvanović, F., Ivanković, M., Lasić, M., Vaško, Ž.(2014) The impact of foreign trade in agricultural products of Bosnia and Herzegovina within the framework of CEFTA 2006, Economics of Agriculture, (61) 4 (975-987),

5. Ćejvanović F., Džafić, I. (2011), CEFTA agreement 2006 and the effects on foreign trade - case Bosnia and Herzegovina, Knego i dr.(ur), International conference "Trade as a drive in development of Middle and Southeast Europe" Collection of works from Faculty of Economics Zagreb.

6. Ćejvanović F., Miličević, D., Kamerić, A. (2018): The application of the gravity model in the evaluation of the foreign trade of agricultural and food products between Bosnia and Herzegovina and Montenegro, International Journal of Sales, Retailing and Marketing, Vol. 7, No. 1, 2018

7. Frankel, J. ( 1997) Regional Trading Blocs. Washington: Institute for International Economics

8. http://www.cefta2006.com/ (19.10. 2017.)

9. Jovanović, M. N. (1998), International Economic Integration, Rotledge, London

10. Kovačević, M. (2002), International trading, Faculty of Economics, Belgrade, p. 379. 
11. Kovačević Zoran i Tomislav Sekur (2012), Export strategy of small open economy in relation to European Union and CEFTA, Collection of scientific works: Development strategy of small national economy in globalized worl (ur. 9. Družić, G.; Družić, I., publisher: Faculty of Economics Zagreb; Croatian Academy of art and science), 2012, vol. 1, pp. 281-301.

12. Mahmutović H., Hodžić K. i Ćejvanović F. (2017): Ekonomska politika otvorene ekonomije, Ekonomski fakultet Univerziteta u Zenici.

13. Nikolić, I. (2015): Primena gravitacijskog modela u identifikaciji determinante razmjene EU i Republike Srbije doktorska disertacija, Sveučilište Megatrend, Fakultet za međunarodnu ekonomiju, Beograd.

14. Regional Free Trade Agreements of Bosnia and Herzegovina: analyses and policy Recommendations (2007) CASE, Center for social and economic research, Warsaw, Poland, February, 2007.

15. Šošić, V,. Vujčić B. (2005), Trade integration and Croatian joining to the EU, Institute for Public Finances, Foundation Friedrich Ebert, Zagreb.

16. Tinbergen, J. (1962) Shaping the World Economy; Suggestions for an International Economic Policy. Books (Jan Tinbergen). Twentieth Century Fund, New York.

17. Unković M. (2010) International Economy, Univerzitet Singidunum, Belgrade.

18. Wijkman, M. (2007) Protection measures provided in CEFTA 2006, a comparison of Article 23 and Article 23 bis, Presentation to the Parliamentarians, Sarajevo, 19. July 2007.

19. Winters, L. A., Wang, Z. K., (1994). Eastern Europe’s International Trade, Trade. Manchester: Manchester University Press. 


\title{
UPOTREBA MODELA GRAVITACIJE U PROCJENJIVANJU VANJSKE TRGOVINE IZMEĐU BOSNE I HERCEGOVINE I CRNE GORE KAO ČLANICA CEFTA UGOVORA 2006
}

\author{
Ferhat Ćejvanović ${ }^{4}$, Dragovan Miličevićs \& Adnan Kamerićc
}

\section{Sažetak}

Analiza vanjske trgovine u današnjoj globalnoj trgovini zahtijeva upotrebu makro analitičkih aktivnosti utemeljenih na suvremenim i klasičnim metodama procjene, mjerenju trgovine $i$ makroekonomskim pokazateljima gospodarske stabilnosti $i$ rasta. Ovaj rad polazi od ideje i potrebe za procjenom utjecaja vanjske trgovine Bosne i Hercegovine upotrebom modela gravitacije. Cilj rada temelji se na ovoj ideji i reflektira se u prednostima i nedostacima korištenja modela gravitacije prilikom procjene vanjske trgovine izmedu Bosne i Hercegovine i Crne Gore.

Model gravitacije u vanjskoj trgovini procjenjuje potencijal među određenim zemljama uzimajući u obzir stvarnu vrijednost trgovanja. Također uzima u obzir potencijal $i$ troškove trgovanja, kao i udaljenost analiziranog tržišta. Ovaj rad polazi od pretpostavke da upotreba modela gravitacije može procijeniti potencijal uvoza i izvoza između dvije zemlje te je na taj način moguće dati pretpostavke o načinima povećanja konkurentnosti među trgovačkim društvima. Rad predstavlja potencijal za uvoz u i izvoz iz Bosne $i$ Hercegovine na temelju rezultata istraživanja. Izvori podataka koji su korišteni u ovom radu prvenstveno su statističke publikacije Bosne i Hercegovine i Crne Gore, kao i podaci dostupni na internetu.

Ključne riječi: vanjska trgovina, model gravitacije, procjena, Sporazum CEFTA 2006, gospodarski rast.

JEL klasifikacija: F12

4 Ferhat Ćejvanović, vanjski suradnik, Ekonomski fakultet Univerziteta u Tuzli, Tuzla, Bosna i Hercegovina, E-mail:ferhat.cejvanovic@gmail.com

5 Dragovan Miličević, VIPOS, Visoka poslovna škola strukovnih studija, Valjevo, Srbija, E-mail: dragovan. milicevic@gmail.com

6 Adnan Kamerić, doktorand, Univerzitet „Vitez“ Travnik, Bosna i Hercegovina, E-mail: ado_kamera@hotmail.com 